\title{
$\mathrm{BIM}$ 기반 철근콘크리트구조의 물량산출 비교
}

\author{
윤 종 $﹎{1}{ }^{\dagger} \cdot$ 조 ${\text { 현 } \text { 식}^{2} \cdot \text { 이 재 } \overline{ }^{3} \cdot \text { 신 재 } \text { 용 }^{4} \text { 김 은 석 }}^{5}$ \\ ${ }^{1,2}$ (주)토문건축사사무소 기술연구소 상무, 팀장, ${ }^{3}$ (주)글로텍 BIM 사업본부 팀장, ${ }^{4}$ 라인테크 BIM 사업본부 팀장, ${ }^{5}$ 창소프트 기술영업팀 대표
}

\section{A Comparison of Quantity Take-Offs of RC Structures based on BIM}

\author{
Jong Deok Yoon ${ }^{1 \dagger}$, Hyun Sik Cho ${ }^{2}$, Jae Hong Lee ${ }^{3}$, Jae Yong Shin ${ }^{4}$ and Eun Suk Kim ${ }^{5}$ \\ ${ }_{1,2}^{1,2}$ anaging Director, Team Leader, Division of Research, Tomoon Architects., Seoul, 05839, Korea \\ ${ }^{3}$ Team Leader, Division of BIM Business, Glotech., Seoul, 08390, Korea \\ ${ }^{4}$ Team Leader, Division of BIM Business, Linetech., Seoul, 06729, Korea \\ ${ }^{5}$ CEO, Division of Technical Business, Changsoft., Seoul, 06173, Korea
}

\begin{abstract}
In the construction industry, there is a growing demand for the accurate calculation of the quantity take-off and construction budget at the design stage, and it is likewise important to grasp changes in the construction budget and quantity take-off if design alterations are made. In addition, lawsuits related to the quantity take-off and cost of construction are frequent; therefore, the calculation of these factors using building information modeling (BIM) has emerged as an alternative. However, existing 2D-based methods are still used more frequently than BIM-based methods for quantity take-offs and construction budgets. This is because of the lack of BIM experience of estimation workers and the absence of a national standard. However, from a designer's point of view, it is necessary to understand the quantity take-off and construction cost based on BIM and accurately create the design according to the budget. In this study, the quantity take-offs of concrete, rebar, and reinforced concrete structures (apartments) in Seoul and Yeongjong were compared with the quantity take-offs based on 2D and BIM methods. From the viewpoint of the designer, we aim to increase the accuracy of BIM-based quantity take-offs.
\end{abstract}

Keywords : quantity take-off, preliminary cost estimation, building information modeling (BIM)

\section{1. 서 론}

\section{1 연구의 배경 및 목적}

건축설계서비스라는 건축공사를 하기 위한 도서를 작성하 는 큰 범위의 업무에서 물량산출 및 견적의 업무는 설계도면을 작성하는 업무와는 별도로 분리되어 견적전문가가 수행하며, 기본설계 후에 개산견적, 실시설계 이후 상세견적을 산출하는 단계별 설계도면 작성이 완료된 이후에 업무를 수행하고 있다.

이러한 이유로 설계자는 물량산출 및 견적을 실시간으로 파 악할 수 없고, 각 설계단계의 도면 작성이후 산출작업을 마치고 나서야 이를 파악할 수 있다. 이때 산출된 견적이 발주자의 예정 공사비에 근접하지 못하는 경우 설계의 변경 작업이 수반되며 시간과 인력의 추가 투입으로 설계자의 부담이 되고 있다.

\footnotetext{
${ }^{\dagger}$ Corresponding author:

Tel: +82-2-2018-8183; E-mail: jdyoon@tomoon.co.kr Received October 12019 ; Revised ; October 82019 Accepted November 192019

(C) 2020 by Computational Structural Engineering Institute of Korea
}

설계자 입장에서는 BIM을 활용하여 설계를 진행하여도 도 면작성업무 완료 이후, 예정공사비를 맞추지 못한 경우, 같은 상황에 놓이게 되며 $\mathrm{BIM}$ 활용의 이점이 줄어들게 된다.

기존의 $\mathrm{BIM}$ 기반의 수량산출 및 견적에 대한 연구 또한 주 로 모델링 가이드라인, 모델링의 정확성, 수량산출 프로세스 등 물량산출과 견적업무의 입장에서 어떻게 모델링을 하고 어 떻게 물량을 산출할 것인가에 초점이 맞추어져 왔다.

따라서 설계자가 BIM 모델의 정보를 이용하여 즉각적이고, 정확한 물량과 견적을 모니터링할 수 있다면, $\mathrm{BIM}$ 을 활용한 설계자의 업무효율을 향상시키고, 전체 설계품질을 높일 수 있을 것으로 기대된다.

최근 다양한 BIM 모델의 데이터를 활용할 수 있는 소프트 웨어들이 개발, 출시되면서 사업초기단계에 매스형태의 모델

This is an Open-Access article distributed under the terms of the Creative Commons Attribution Non-Commercial License(http://creativecommons. org/licenses/by-nc/3.0) which permits unrestricted non-commercial use, distribution, and reproduction in any medium, provided the original work is properly cited. 
로부터 LOD 200 300의 상세모델까지 모델로 부터 재료, 길 이, 면적, 부피 등의 정보와 산출식, 일위대가의 데이터를 연결 하여 모델링되지 않은 부재 및 공종의 물량산출과 견적도 실시 간으로 수행할 수 있게 되었다.

본 사례연구는 설계 기획단계에서 물량 및 견적을 산출할 수 있는 $\mathrm{A}$ 제품와 기본, 실시설계 단계에서 물량 및 견적을 산 출할 수 있는 $\mathrm{B}$ 제품, 실시설계단계에서 콘크리트구조의 수량 을 산출할 수 있는 $\mathrm{C}$ 제품, 3 가지 소프트웨어들을 이용하여 두 가지 테스트 프로젝트를 통해 산출된 콘크리트, 거푸집, 철근 물량들을 기존의 2D CAD도면을 바탕으로 산출한 물량과 비 교하여 차이를 알아보고, 원인을 분석하여 문제점을 도출하여 해결방안을 제시하고가 되고자 한다.

\section{2 연구동향 분석}

$\mathrm{BIM}$ 모델을 활용한 물량산출 및 견적에 관련된 국내의 연 구 문헌을 조사한 결과는 Table 1과 같다.

$\mathrm{BIM}$ 기반 물량산출, 견적과 관련한 연구는 최근 10 여 년간
꾸준히 이루어져 왔다. 기존의 연구들을 살펴보면 BIM기반의 개산견적에 대한 연구가 가장 많았고, 물량산출을 위한 BIM 데이터 작성기준이나 산출방법에 대한 연구가 진행되었다.

$\operatorname{Min}$ 과 $\operatorname{Kim}(2016)$ 은 공동주택 BIM 모델로부터 재료일람표 기능을 이용하여 콘크리트 물량을 산출하고, $2 \mathrm{D}$ 기반으로 산출 한 물량과 실제 타설량을 비교하여 오차를 분석하였고, BIM 기반의 물량산출이 오류와 실수를 줄이는데 기여할 수 있다는 점을 제시하였다.

Yoo와 Lee(2015)는 마감공사 중 조적공사를 대상으로 BIM 기반과 $2 \mathrm{D}$ 기반의 물량을 산출하여 비교하였는데, $\mathrm{BIM}$ 이 정 확한 설계정보를 제공하고, 사람에 의한 실수를 찾아내는데 효과적임을 제시하였다.

Kim과 Yoon(2013)은 마감공사 물량산출의 정확도를 BIM 기반과 $2 \mathrm{D}$ 기반으로 산출한 물량을 비교하였는데, $\mathrm{BIM}$ 의 유용 함과 모델링의 상세정도에 따른 차이가 나타남을 지적하였다.

기존의 물량산출의 정확도에 관한 연구들이 BIM모델로부 터 직접 산출할 수 있는 물량을 위주로 재료일람표 기능을 이 용하여 산출한 결과를 $2 \mathrm{D}$ 기반으로 산출한 물량과 비교하여

Table 1 Literature review of BIM and quantity takeoff

\begin{tabular}{|c|c|c|c|}
\hline & Author & Title & Year \\
\hline \multirow{6}{*}{$\begin{array}{c}\text { Quantity } \\
\text { Take- } \\
\text { off } \\
\text { Case } \\
\text { Study }\end{array}$} & Lee, Jae-Hong & BIMbased Reinforced Concrete Work Quantity and Cost Esimate Method & 2017 \\
\hline & Min, Kyoung-Hwan et al. & Comparison Analysis of Concrete Material Take-off of Structural Frame Work Based on BIM & 2016 \\
\hline & Yoo, Ji-Eun et al. & Comparison of Quantity Take-off Based on BIM and 2D & 2015 \\
\hline & Kim, Ji-Hyun et al. & A Verification of the Accuracy in BIM-Based Quantity Taking-Off-Focusing on Finishing Work & 2013 \\
\hline & Shin, Jae-Choull et al. & $\begin{array}{l}\text { Analysis of Errors and Reliability in Earth-Volume and Retaining wall Quantity Estimation with 3D-BIM } \\
\text { Compared with Routine Method Based 2D }\end{array}$ & 2013 \\
\hline & Lee, Moon-Kyu et al. & A Study on the Accuacy of BIM-based Quantity Take-off of Apartment Interior & 2013 \\
\hline \multirow{10}{*}{$\begin{array}{c}\text { Preliminary } \\
\text { Estimate }\end{array}$} & Yang, Hyunchul et al. & Implementation of BIM-based Approximate Extimate System Considering Life-Cycle Cost & 2016 \\
\hline & Song, Chi-Ho et al. & Establishment of Rebar Quantity Estimation in BIM-based Initial Design Phase & 2016 \\
\hline & $\mathrm{Na}$, Suncheol et al. & Application of BIM for Preliminary Cost Estimate in Early Design Phase & 2015 \\
\hline & Lim, Jin-Kang et al. & BIM-based Preliminary Estimate for Decision-Making in Conceptual Design Phase & 2015 \\
\hline & Yoon, Myuong-Chul & Architectural Design Considering the Composed Unit Cost of BIM Rough Estimation Research & 2013 \\
\hline & Kim, Han-Saem et al. & A Methodology of Open BIM-Based Quantity Take-Off for Schematic Estimation of Frame Work in Super-Tall Buildings & 2013 \\
\hline & Jun, Ki-Hyun et al. & Preliminary Study on the Construction of Database for BIM-based preliminary estimate & 2012 \\
\hline & Park, Young-Jin et al. & A Study on 3D BIM Collaboraive Approximate Estimationg Model of Structural Work for Apartment Projects & 2011 \\
\hline & Park, Young-Jin et al. & Development of an Approximate Estimation Model using Space Factor and BIM Collaboration & 2009 \\
\hline & Chung, Suwan et al. & Framework of Conceptual Estimation Model for BIM based Internal Finishes of High-rise Building Project & 2014 \\
\hline \multirow{5}{*}{ Guide-Line } & An, Ji-Won et al. & Improvement of BoQ Documents for the BIM based Quantity Takeoff & 2017 \\
\hline & Joo, Seon U et al. & BIM-Based Quantity Takoff and Cost Estimation Guidelines for Reinforced Concrete Structure & 2017 \\
\hline & Kim, Seong-Ah et al. & A Study on Setting Up Work Conditions for Improving Productivity of BIM-based Cost Estimation & 2016 \\
\hline & Kwon, O-Cheol et al. & Introduction of BIM Quality Standard for Quantity Take-off & 2011 \\
\hline & Lee, Chang-Hee et al. & An Index for Measuring the Degree of Completeness of BIM-based Quantity Take-off & 2011 \\
\hline \multirow{3}{*}{ Automation } & Choi, Hyun-Chul et al. & Development of 3-Dimensional Rebar Detail Design and Placing Drawing System & 2014 \\
\hline & Jun, Ki-Hyun et al. & The case study of BIM-based quantity take-off for concrete and framework & 2011 \\
\hline & Kim, Seong Ah et al. & A Development of Finish Drawing Automation System for Improving Efficiency on BIM based Estimation & 2008 \\
\hline \multirow{7}{*}{$\begin{array}{l}\text { Data } \\
\text { Usage }\end{array}$} & Lee, Hae-Chan et al. & BIM-Based cost estimation by integraion with BIM Model data and cost information & 2017 \\
\hline & Cho, Young-Sun et al. & Development of BIM based Estimation Prototype System Using Building Elements Combination Database & 2015 \\
\hline & Yoon, Myoung-Chul et al. & A BIM-Based Architectural Model Takes Advantage of the Estimate Model Process & 2013 \\
\hline & Kim, Han-Joon et al. & The Development of Data Model for Open BIM-Based Schematic Estimates & 2013 \\
\hline & Ahn, Jae-Hong et al. & A Study on the BIM based Estimate and Construction Intergated Management Plan Using WBS-CBS & 2012 \\
\hline & Kim, Young-Jin et al. & A Study of BIM based estimation Modeling data reliability improvement & 2012 \\
\hline & Cho, Young-Sang et al. & $\begin{array}{l}\text { Implementation of Quantity Estimation Database based on Efficiency Analysis of Quantity Information about } \\
\text { BIM of Reinforced Concrete Structure through the Case Study }\end{array}$ & 2009 \\
\hline
\end{tabular}


유용성과 한계점을 제시하고 있으며, 직접 산출이 가능한 파 라메터인 각 부재의 길이, 면적, 부피와 산출식을 이용하여 간 접적인 산출이 가능한 거푸집, 철근 등의 물량이나 부자재, 하 지 등의 물량을 산출하는 사례연구는 미비하였다.

\section{3 연구의 범위 및 방법}

연구의 범위는 가장 일반적이고 많이 사용되는 $\mathrm{RC}$ 구조와 벽식구조 형식의 철근콘크리트구조 건축물 중, 2015 년도 설계 업무를 수행한 서울시에 위치한 $\mathrm{OO}$ 센터 생활관과 2016년 설계 업무를 수행한 영종 $\mathrm{OO}$ 아파트를 대상으로 하여 콘크리트, 거 푸집, 철근의 물량을 기존의 $2 \mathrm{D}$ 도면을 기반으로 산출한 데이터 와BIM모델을 바탕으로 산출한 데이터를 비교·분석하였다.

두 프로젝트 모두 설계 시 2D CAD와 $\mathrm{BIM}$ 작업이 병행으로 진행되었으며, BIM 모델은 Autodesk Revit을 사용하여 구조모 델링을 하였다.

연구의 방법은 Fig. 1 과 같이 기본설계도면을 바탕으로 A제 품을 이용하여 개산견적용 모델을 작성하여 물량산출을 진행 하고, 실시설계도면을 바탕으로 $2 \mathrm{D}$ 기반 물량을 산출하고, 이 단계에 작성한 Revit 모델을 이용하여 B제품에서 물량을 산출 하였다. 프로젝트 완료 후 본 사례연구를 위하여 C제품의 모델 을 추가로 작성하여 물량을 산출하여 각각을 비교 - 분석하여 차이점을 알아보고 원인을 분석하였다.

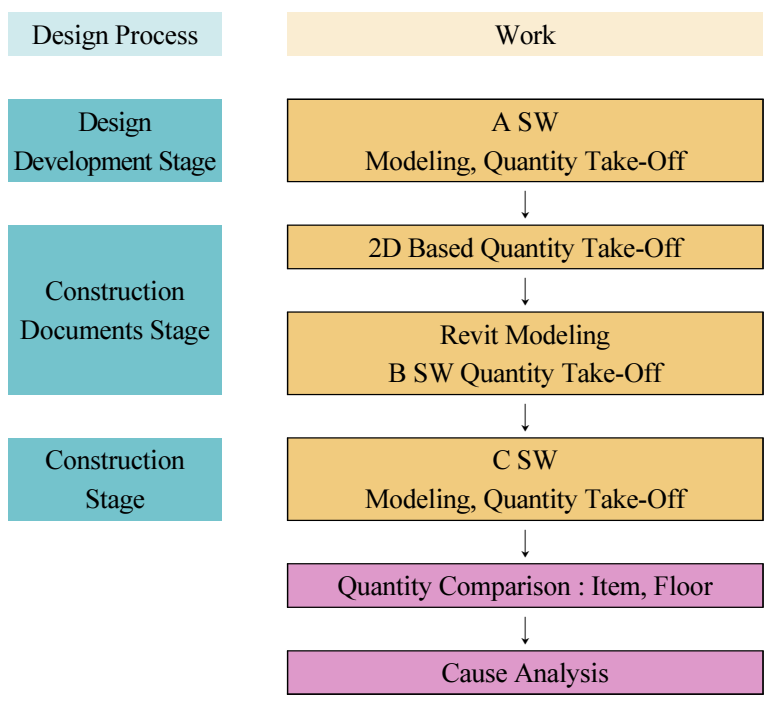

Fig. 1 Working flow chart

\section{BIM기반 철근콘크리트 물량산출 소프트웨어}

\section{1 물량산출 소프트웨어 개요}

현재 BIM기반의 물량을 산출할 수 있는 많은 소프트웨어들 이 개발되어 시판되고 있다. 하지만, $2 \mathrm{D}$ 기반의 물량산출에서도
Table 2 Summary of used software

\begin{tabular}{|c|c|c|}
\hline Item & Feature & $\begin{array}{c}\text { Modeling } \\
\text { Method }\end{array}$ \\
\hline A SW & $\begin{array}{c}\text { Quantity Take-Off from Mass Design in } \\
\text { Schematic Design Stage }\end{array}$ & $\begin{array}{c}\text { Use Own } \\
\text { Modeler }\end{array}$ \\
\hline B SW & Quantity Take-Off from Revit Model(Revit Addon) & Revit Model \\
\hline C SW & Quantity Take-off from RC Structure Model & $\begin{array}{c}\text { Use Own } \\
\text { Modeler }\end{array}$ \\
\hline
\end{tabular}

견적작업자의 경험과 방법에 따라 차이가 발생하듯, 본 사례 연구는 산출 소프트웨어별로 산출 방식의 차이에 의해 어떠한 차이가 발생하는지 알아보고, 그 원인을 분석해 보고자 하였 기에 각각 다른 특성의 소프트웨어를 선정하였으며, 사용된 소프트웨어의 목록과 주요특징은 Table 2와 같다. 각각의 물량 산출 방식은 다음절에서 설명하였다.

\section{$2.2 \mathrm{~A}$ 제품}

본 소프트웨어는 개산견적용으로 초기 사업비 규모를 산정하 거나, 계획 설계 시 건물의 상세 디자인이 나오지 않은 상태에서 매스형태의 모델에서 길이, 면적, 부피 등의 파라메터를 추출하 고, 산출식 데이터베이스와 연동하여 물량 및 공사비를 산출한다.

산출식 데이터베이스는 여러 개의 유사 프로젝트의 도서와 견적내용을 참고하여 작성하였으며, 산출식의 정밀도에 따라 산출된 물량의 정밀도가 달라질 수 있다.

$\mathrm{A}$ 제품에서 거푸집과 철근의 산출은 기본적으로 매스 모델 에서 Z축 상의 레벨에 의해서 생성되는 슬라브(slab)와 X, Y축 상의 중심선(grid)이 제공하는 매개 변수의 정보 값에 크게 의 존한다. 그 이외 부분은 전적으로 이 변수를 이용하여 데이터베 이스 상의 산출식을 어떻게 구성하느냐에 달려있는데, 부족한 부분을 채우기 위해서 사용자 정의 변수를 활용할 수도 있다.

데이터베이스 작성 과정에서 산출식을 단순화하고 쉽게 구성하 기 위해 구조물을 부재별로 구분하는데, $\mathrm{RC}$ 구조물은 수평 부재인 슬라브와 보, 수직 부재인 기둥과 벽체, 그리고 기초로 구분하였다.

슬라브의 산출식을 예로 들면, 거푸집은 슬라브 바닥면적 (Area)으로, 철근은 슬라브 체적에 대한 철근비(Area * Thickness * 철근비)로 산출한다.

\section{$2.3 \mathrm{~B}$ 제품}

본 소프트웨어는 Revit으로 모델링된 각각의 부재 패밀리를 불러들여 속성상의 길이, 면적, 부피정보를 바탕으로 프로그 램에 미리 정의된 산출식을 바탕으로 물량을 산출한다.

거푸집 공종의 경우 Revit의 부재별 패밀리를 불러와 기초 의 경우 테두리 면적의 합을, 보는 보높이 면적*2를, 바닥은 보 와 중첩되는 누락된 보의 폭부분의 면적을 공제하지 않고 합산 
하여 전체 바닥면적을, 기둥은 수직면적의 합을, 벽의 경우 벽 면적*2 등의 부재별 면적(M2) 산출을 위한 자체 계산 알고리 즘을 통해 거푸집 물량을 자동 산출하게 된다.

철근에 대한 물량산출은 Revit의 기초, 바닥, 벽, 보, 기둥, 계단 등의 주요 부재별 패밀리 유형 및 인스턴스의 속성에 구조계산에 의한 철근종류 및 간격 등을 입력하여 자체 철근 물량산출 계산 알고리즘에 의해 철근 종류별 중량(Ton)을 자동 산출하게 된다.

\section{$2.4 \mathrm{C}$ 제품}

본 소프트웨어는 각각의 부재에 배근정보를 입력하여 배근 모델링, 철근의 샵도서작성, $3 \mathrm{D}$ 골조 형상을 기반으로 철근, 콘크리트, 거푸집 물량을 산출한다.

콘크리트의 경우 콘크리트 재료특성과 견적지침에 따른 수 량산출옵션(철근 체적공제, 합벽, 단차부위 등)이 적용되고 있 으며, 거푸집의 경우 각 층별, 위치별 거푸집 타입(유로폼, 알 폼, 합판 3 회 등)을 설정하여 산출한다.

가장 큰 특징은 철근 수량산출 방식으로 기존 소프트웨어가 단순히 철근 수량산출을 주어진 골조 형상정보와 계산식에 따 라 결과를 산출하는 반면, $\mathrm{C}$ 제품에서는 시공 상세에 따른 철 근 모델링을 자동으로 완성할 수 있어 실제 철근배근의 적정성 유무 및 다양한 시공 상세별 철근물량을 확인할 수 있다.

\section{3. 대상건물 개요 및 수량산출 수행 개요}

\section{1 서울시 $\mathrm{OO}$ 센터 생활관}

서울시 $\mathrm{OO}$ 센터 생활관의 개요는 Table 3 과 같다.

본 건물은 전형적인 RC구조로 Fig. 2 와같이 지하 1층에서 6 층 까지 층별 변화가 거의 없이 동일한 구조가 반복되는 형태이다.

\begin{tabular}{|l|r|}
\hline \multicolumn{1}{|l|}{ Table 3 Summary of dormitory } \\
\hline \\
\end{tabular}
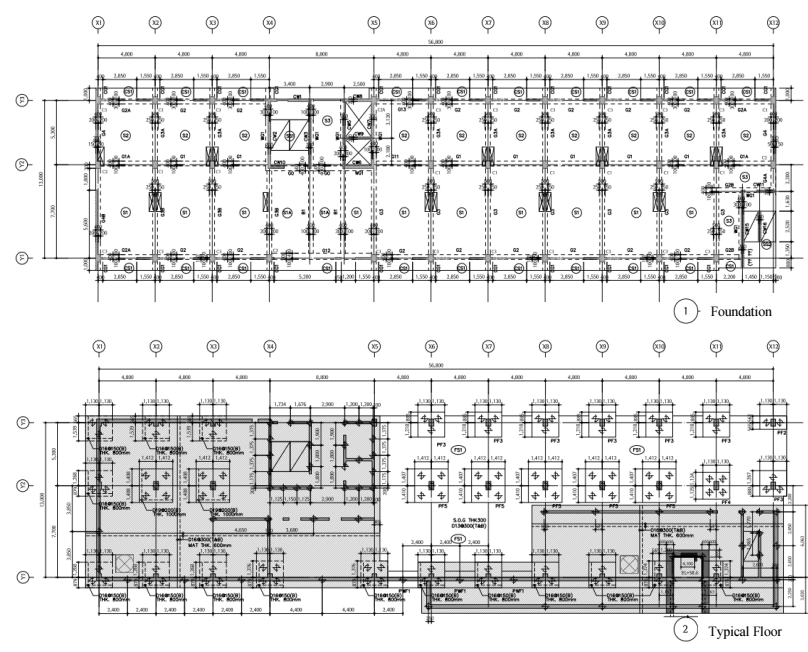

Fig. 2 Structural drawing of typical plan, foundation

전면의 모듈은 $4,800 \mathrm{~mm}$ 이고 코어 주변의 모듈은 $8.800 \mathrm{~mm}$, 지 하 1 층의 일부는 대지 고저차를 이용하여 필로티 주차장으로 계획 되었으며, 기초형식은 매트기초와 파일기초가 혼합 사용되었다.

각 물량 산출을 위한 모델을 다음과 같이 작성하였다.

$\mathrm{A}$ 제품은 축열과 층 레벨을 설정하고, 외곽선 형태를 따라 매스형태를 작성하였고, 완성된 모델은 Fig. 3 과 같다.

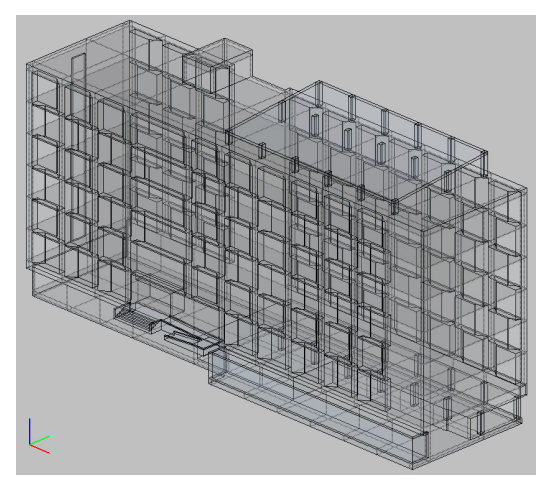

Fig. 3 A Software model

$\mathrm{B}$ 제품의 레빗모델은 층별, 부재별로 작성되었으며, 슬라브 는 각각의 보에 의해 둘러싸인 형태로 작성하여 부재의 중복을 피하였다. 완성된 모델은 Fig. 4와 같다.

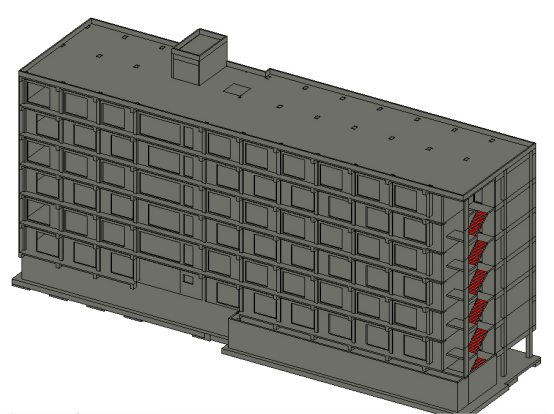

Fig. 4 Revit model 
철근의 배근 정보는 Fig. 5 와 같이 각 부재별로 패밀리의 인 스턴스로 입력하였다.

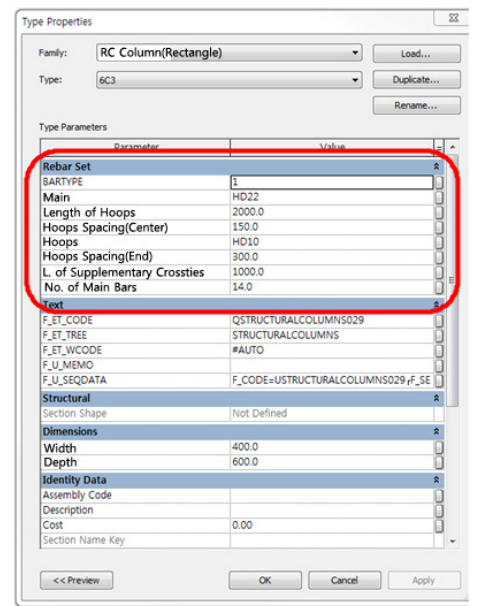

Fig. 5 Revit family instance(rebar)

C제품 모델작성은 먼저 Fig. 6 과 같이 구조일반 사항의 배근 관련 정보들을 입력하고, 층고를 설정한 뒤 캐드로 작성된 구 조일람표의 부재명, 크기와 배근정보를 인식시켜 모델링에 필 요한 부재들을 생성하고, 구조평면도를 불러와 도면상의 부재 명을 인식시켜 자동으로 $3 \mathrm{D}$ 모델을 작성하고, 인식이 되지 않 는 부분들은 수동으로 배근정보와 형상을 입력하여 모델을 작 성하였다. 완료된 모델은 Fig. 7과 같다.

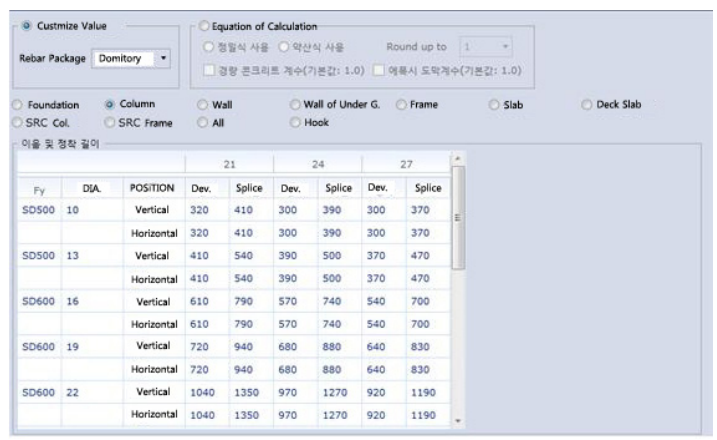

Fig. 6 Dev. \& splice setup

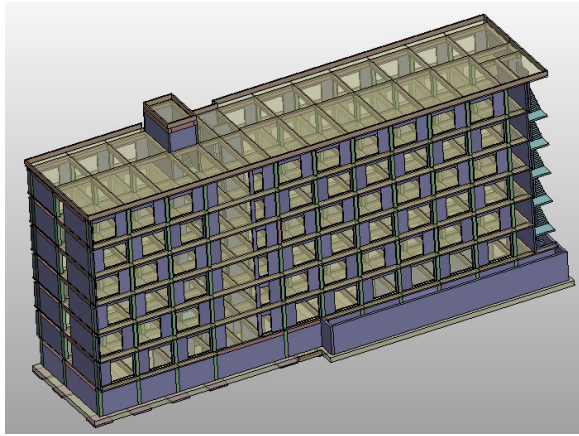

Fig. 7 C software model
각각의 모델이 완료된 후, 콘크리트, 거푸집, 철근의 물량을 전체, 부재별로 산출하였다.

\section{2 영종 $\mathrm{OO}$ 아파트}

본 연구를 위하여 아파트단지 전체 18 개 동 중 1 개 동을 선 택하여 모델링과 물량산출을 진행하였다.

작업을 수행한 1 개 동의 개요는 Table 4 와 같다.

Table 4 Summary of apartment

\begin{tabular}{|l|}
\hline \\
\hline
\end{tabular}

본 건물은 Fig. 8 과 같이 벽식구조로 2 27층까지 동일한 구 조 형태이며, 1 층은 피로티로 계획하였으며, 구조설계 방법이 일반적인 전단벽 설계가 아닌 성능기반 설계를 적용하여 일반적 인 벽식구조 형식의 철근 배근방법과 차이가 있기 때문에 배근 방법의 차이에 따른 철근 물량의 차이를 검토해 보고자 하였다.

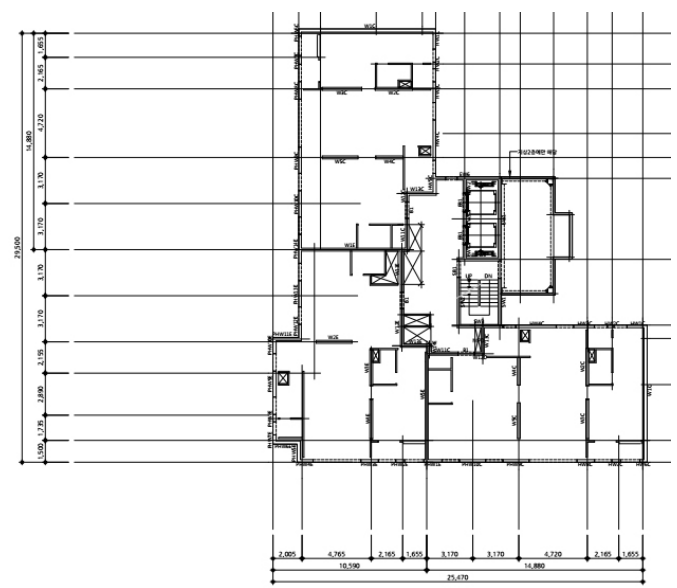

Fig. 8 Structural drawing of typical plan 
벽식구조물의 경우, $\mathrm{A}$ 제품은 축열과 층고에 의해 구조물량 을 산출을 하지 못하기 때문에 건물의 외곽선을 따라 매스로 형태를 만들었으며 완료된 모델은 Fig. 9와 같다. 물량산출은 단위세대 크기에 따라 데이터베이스에 미리 만들어 놓은 산출 식을 이용하여 콘크리트, 거푸집, 철근 물량을 산출하였다. 본 연구에 사용된 데이테베이스의 산출식은 이전에 수행하였던 5 개의 프로젝트의 $2 \mathrm{D}$ 기반의 산출물량을 바탕으로 단위세대 의 크기, 코어의 형태별로 평균을 내어 작성하였다.

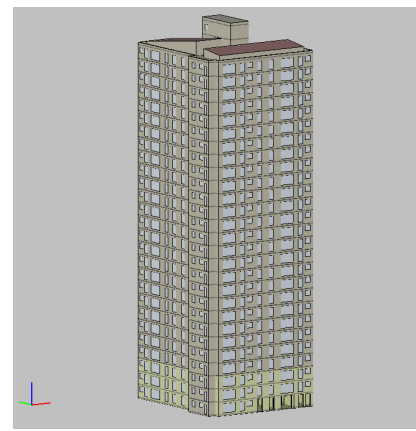

Fig. 9 A Software model

$\mathrm{B}$ 제품을 이용하기 위한 레빗모델은 부재별, 층별로 작성하 였고, 작성된 모델은 Fig. 10과 같다. 배근정보는 Fig. 11 과 같이 부재 패밀리의 인스턴스로 입력하였다.

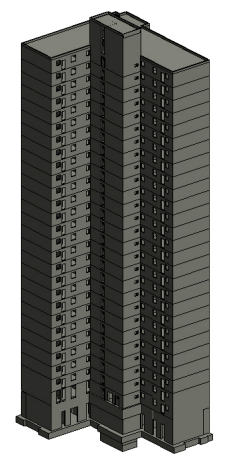

Fig. 10 Revit model

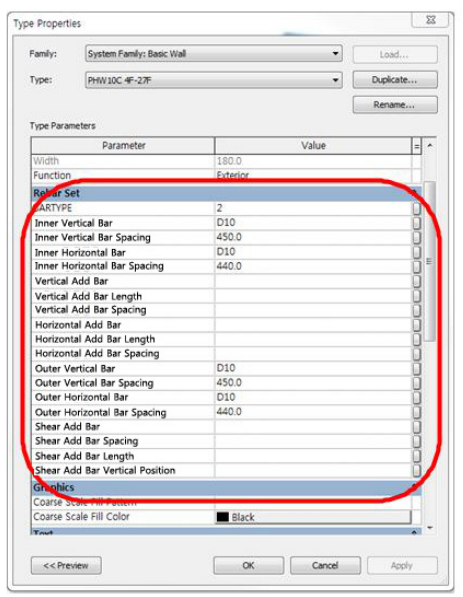

Fig. 11 Revit family instance(rebar)
$\mathrm{C}$ 제품 모델은 앞의 생활관과 동일한 방법으로 구조일반사 항 입력, 일람표와 도면인식, 미 인식부분의 수동모델링의 순 서로 작성하였으며, 완료된 모델은 Fig. 12와 같다.

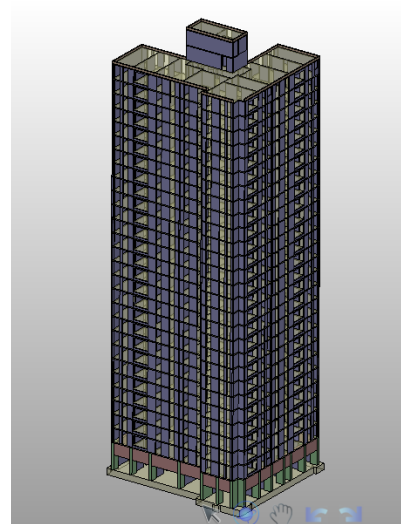

Fig. 12 C Software model

\section{4. 물량산출 결과 및 비교 분석}

\section{1 서울 00 센터 생활관}

생활관의 물량산출 결과는 Table 5 와 같이 나타났다.

$2 \mathrm{D}$ 기반 물량을 기준으로 각 소프트웨어별 물량을 비교해 보면, 콘크리트 물량산출 결과는 A제품에서 산출한 물량이 $0.1 \%$ 로 가장 유사하게 나타났으며, B제품에서 산출한 물량이 $-10.0 \%$ 로 가장 큰 차이를 보였다.

거푸집 물량의 경우는 B제품에서 산출한 물량이 $0.5 \%$ 차이 로 가장 적었고, $\mathrm{A}$ 제품과 $\mathrm{C}$ 제품에서 산출한 물량이 각각 $4.3 \%$ 와 $-3.7 \%$ 로 유사한 차이로 많거나 적게 산출되었다.

철근 물량은 모두 $2 \mathrm{D}$ 기반 물량과 큰 차이를 나타내었다. 모 두 약-8 -27\%까지 적게 산출이 되었는데, $\mathrm{A}$ 제품, $\mathrm{C}$ 제품, $\mathrm{B}$ 제 품의 순서로 차이가 나타났다.

Table 5 Comparison of 2D-base and BIM base quantity take-off

\begin{tabular}{|c|r|r|r|}
\hline Item & Concrete $\left(\mathrm{m}^{3}\right)$ & \multicolumn{1}{|c|}{ Form $\left(\mathrm{m}^{2}\right)$} & Rebar(Ton) \\
\hline 2D-Base(1) & 2,842 & 15,616 & 278 \\
\hline A SW(2) & 2,839 & 16,295 & 256 \\
\hline$(2)-(1)$ & -3 & 679 & -22 \\
\hline Diff.((2)-(1)/(1)) & $\mathbf{- 0 . 1 \%}$ & $\mathbf{4 . 3 \%}$ & $\mathbf{- 7 . 9 \%}$ \\
\hline B SW(3) & 2,557 & 15,697 & 203 \\
\hline$(3)-(1)$ & -285 & 81 & -76 \\
\hline Diff.((3)-(1)/(1)) & $\mathbf{- 1 0 . 0 \%}$ & $\mathbf{0 . 5} \%$ & $\mathbf{- 2 7 . 2 \%}$ \\
\hline C SW(4) & 2,691 & 15,039 & 234 \\
\hline$(4)-(1)$ & -151 & -577 & -44 \\
\hline Diff.((4)-(1)/(1)) & $\mathbf{- 5 . 3 \%}$ & $\mathbf{- 3 . 7 \%}$ & $\mathbf{- 1 5 . 8 \%}$ \\
\hline
\end{tabular}


각 프로그램별로 원인을 찾아보면, $\mathrm{A}$ 제품은 기존의 유사한 프로젝트들의 $2 \mathrm{D}$ 기반 물량을 바탕으로 산출식을 도출하여 물량을 산출하므로 전형적인 $\mathrm{RC}$ 구조의 경우 $2 \mathrm{D}$ 기반에서 산 출한 물량과 가장 유사하게 나타남을 알 수 있었다.

다만, 철근의 물량이 비교적 차이가 많이 나는 것은 콘크리 트 물량에 대한 철근비로 수량을 산출하는데, 철근비가 예측 치보다 적었기 때문인 것으로 파악되었다.

$\mathrm{B}$ 제품의 경우 레빗 모델의 각 부재 패밀리의 형상관련 정보 중, 부피는 콘크리트, 표면적은 거푸집 면적으로 프로그램 내 부의 알고리즘을 통해 산출하게 된다.

철근물량은 각 부재별 형상정보에 $2 \mathrm{D}$ 기반 산출 방법과 유 사하게 배근정보를 연동하여 산출하도록 되어 있어 거의 정미 량에 가깝게 산출이 된다. 하지만 이음이나 정착, 보강근, 보조 근 등의 산출식이 일부분 적용이 되어 있지 않아 차이가 나타 나는 것으로 파악되었다.

$\mathrm{C}$ 제품의 경우는 프로그램 상에서 각종 물량 산출과 관련된 템플릿을 제공하고, 이를 미리 설정하여 부재의 겹침 시 콘크 리트의 공제, 거푸집의 공제 및 부위, 철근의 이음, 정착, 보강, 마구리면, 보조근 등의 물량을 산출할 수 있도록 되어 있어, $2 \mathrm{D}$ 기반 산출물량과 차이가 발생하였지만, $\mathrm{A}$ 제품과 $\mathrm{B}$ 제품에서
산출한 물량의 중간정도로 나타났다.

각 부재별로 물량을 비교한 결과는 Table 6과 같다.

$\mathrm{A}$ 제품에서 산출한 콘크리트 물량은 보가 가장 많은 차이로 $13.62 \%$, 가장 적은 차이는 슬라브로 $-1.34 \%$ 로 나타났는데, 부 재의 크기가 결정된 후에 물량을 산출하는 방식이 아니고 개략 적인 크기를 가정하여 물량을 산출하는 방식이기 때문에 보의 경우 구조설계가 완료된 이후와는 크기의 차이가 발생하기 때 문이며 슬라브의 경우는 일반적인 RC구조 슬라브의 두께 차 이가 크지 않기 때문인 것으로 파악되었다. 거푸집 물량의 경 우는 기초가 $36.18 \%$ 로 가장 크고, 슬라브가 $3.86 \%$ 로 가장 적 은 것으로 나타났다. 이는 MAT기초 부분을 슬라브로 산출하 기 때문인 것으로 파악되었다. 철근 물량의 경우 가장 크게 차 이가 나타난 부재는 기둥으로 $-57.44 \%$, 가장 차이가 적은 것은 기초로 $6.06 \%$ 로 나타났다. 이는 역시 부재의 사이즈를 가정하 여 산출하는 방식이 원인으로 파악되었다.

$\mathrm{B}$ 제품에서 산출한 콘크리트 물량은 슬라브가 $-25.80 \%$ 로 가장 크고, 계단이 $-22.50 \%$, 가장 작은 것은 벽으로 $0.65 \%$ 의 차이를 나타내었다.

이는 슬라브 산출시 보와 겹치는 부분을 보로 산출하기 때 문인 것으로 파악되었다.

Table 6 Comparison of 2D-base and BIM base quantity take-off(elements)

\begin{tabular}{|c|c|c|c|c|c|c|c|c|c|c|c|c|}
\hline & & $\mathrm{m}$ & 2D Base & A SW & A SW-2D & Diff. to $2 \mathrm{D}(\%)$ & B SW & B SW-2D & Diff. to $2 \mathrm{D}(\%)$ & C SW & C SW-2D & Diff. to $2 \mathrm{D}(\%)$ \\
\hline & $\stackrel{T}{0}$ & Concrete & 636.03 & 603.42 & -32.61 & $-5.13 \%$ & 528.68 & -107.34 & $-16.88 \%$ & 580.80 & -55.23 & $-8.68 \%$ \\
\hline & 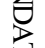 & Form & 163.89 & 223.18 & 59.29 & $36.18 \%$ & 384.39 & 220.50 & $134.54 \%$ & 204.27 & 40.38 & $24.64 \%$ \\
\hline & $\bar{z}$ & Rebar & 27.27 & 28.92 & 1.65 & $6.06 \%$ & 21.06 & -6.21 & $-22.76 \%$ & 20.69 & -6.57 & $-24.11 \%$ \\
\hline & 2 & Concrete & 186.58 & 178.01 & -8.57 & $-4.59 \%$ & 194.27 & 7.70 & $4.13 \%$ & 185.24 & -1.34 & $-0.72 \%$ \\
\hline & 5 & Form & $1,551.12$ & $1,468.80$ & -82.32 & $-5.31 \%$ & $1,615.11$ & 63.99 & $4.13 \%$ & $1,540.11$ & -11.01 & $-0.71 \%$ \\
\hline & $Z$ & Rebar & 59.85 & 25.29 & -34.56 & $-57.74 \%$ & 43.39 & -16.46 & $-27.50 \%$ & 57.96 & -1.88 & $-3.15 \%$ \\
\hline$\frac{a}{0}$ & 격 & Concrete & 471.34 & 535.51 & 64.18 & $13.62 \%$ & 536.39 & 65.05 & $13.80 \%$ & 460.79 & -10.55 & $-2.24 \%$ \\
\hline 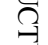 & 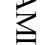 & Form & $2,130.08$ & $2,310.70$ & 180.62 & $8.48 \%$ & $2,337.43$ & 207.35 & $9.73 \%$ & $2,954.20$ & 824.12 & $38.69 \%$ \\
\hline $\bar{\nabla}$ & Q & Rebar & 66.36 & 74.95 & 8.59 & $12.94 \%$ & 58.71 & -7.66 & $-11.54 \%$ & 63.07 & -3.29 & $-4.96 \%$ \\
\hline 표 & & Concrete & 924.81 & 912.39 & -12.41 & $-1.34 \%$ & 686.22 & -238.58 & $-25.80 \%$ & 918.27 & $(6.54)$ & $-0.71 \%$ \\
\hline 而 & 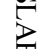 & Form & $5,950.03$ & $6,179.91$ & 229.88 & $3.86 \%$ & $4,574.81$ & $-1,375.22$ & $-23.11 \%$ & $4,736.00$ & $-1,214.03$ & $-20.40 \%$ \\
\hline 兵 & & Rebar & 57.04 & 62.05 & 5.01 & $8.79 \%$ & 46.73 & -10.30 & $-18.07 \%$ & 50.27 & -6.77 & $-11.87 \%$ \\
\hline & & Concrete & 555.58 & 609.86 & 54.28 & $9.77 \%$ & 559.18 & 3.60 & $0.65 \%$ & 491.68 & -63.90 & $-11.50 \%$ \\
\hline & 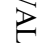 & Form & $5,419.09$ & $6,112.15$ & 693.06 & $12.79 \%$ & $6,361.25$ & 942.16 & $17.39 \%$ & $5,287.49$ & -131.60 & $-2.43 \%$ \\
\hline & & Rebar & 59.80 & 64.54 & 4.74 & $7.92 \%$ & 26.48 & -33.32 & $-55.72 \%$ & 37.42 & -22.38 & $-37.43 \%$ \\
\hline & & Concrete & 67.79 & & & & 52.53 & -15.26 & $-22.50 \%$ & 53.88 & -13.90 & $-20.51 \%$ \\
\hline & $\vec{B}$ & Form & 402.13 & & & & 424.39 & 22.26 & $5.54 \%$ & 316.78 & -85.35 & $-21.22 \%$ \\
\hline & & Rebar & 8.02 & & & & 6.31 & -1.71 & $-21.34 \%$ & 4.92 & -3.10 & $-38.66 \%$ \\
\hline
\end{tabular}


계단의 경우 $2 \mathrm{D}$ 기반으로 산출시 계단의 부피를 산출하지 않고 사면의 길이에 평균 두께를 곱하여 계산하는데 반해, BIM 모델을 이용할 경우 정확한 부피를 계산하기 때문인 것으로 파 악되었다.

거푸집의 물량은 기초가 $134.54 \%$ 로 가장 크고 기둥이 4.13 $\%$ 로 가장 작은 차이를 나타내었다. 마찬가지로 기초의 경우 슬라브에 포함되는 부분이 있어서 큰 차이를 나타내었다.

C제품에서 산출한 콘크리트 물량은 계단이 $-20.51 \%$ 로 가 장 크고, 기둥과 슬라브가 $-0.7 \%$ 정도로 가장 차이가 작았다. 이는 앞의 B제품과 마찬가지로 계단의 산출방식이 다르기 때 문인 것으로 파악되었다.

\section{2 영종 00 아파트 물량산출 결과 및 비교}

물량산출의 결과는 Table 7과 같이 나타났다.

앞의 생활관 사례와 크게 차이를 보인 부분은 $\mathrm{A}$ 제품에서 산출한 물량이 모두 $2 \mathrm{D}$ 기반 산출 물량보다 크게 나타났다는 점이다. 콘크리트, 철근의 물량은 각각 $4.4 \%, 3.7 \%$ 많이 산출 되었고, 거푸집은 $1.1 \%$ 로 거의 유사하게 산출되었다.

콘크리트 물량의 경우 $\mathrm{B}$ 제품과 $\mathrm{C}$ 제품 모두 $-0.2 \sim 1.0 \%$ 정도 로 매우 유사하게 산출되었으며, 거푸집은 C제품에서 산출한 물량이 $-6.3 \%$ 로 비교적 큰 차이를 보였다. 철근 물량은 앞의 생활관과 마찬가지로 $\mathrm{B}$ 제품, $\mathrm{C}$ 제품에서 산출한 물량이 큰 차 이를 보였는데, 각각 $-21.8 \%,-17.2 \%$ 의 차이가 나타났다.

차이가 발생한 원인을 각각 파악해 보면 $\mathrm{A}$ 제품의 경우는 기 존 다수 프로젝트의 $2 \mathrm{D}$ 기반의 산출물량들을 이용하여 단위세 대 크기에 따라 산출식을 작성하였기 때문에 비교적 차이가 적 게 나타난 것으로 파악되었다.

$\mathrm{B}$ 제품의 경우 아파트 주동의 구조적 특성이 슬라브와 벽체 로 이루어져 있어, 형상의 겹침 등이 적어지는 특성이 있어 부 피와 면적이 크게 차이가 나지 않기 때문에 $2 \mathrm{D}$ 기반 물량과 크

Table 7 Comparison of 2D-base and BIM base quantity Take-off

\begin{tabular}{|c|r|r|r|}
\hline Item & Concrete $\left(\mathrm{m}^{3}\right)$ & Form $\left(\mathrm{m}^{2}\right)$ & Rebar(Ton) \\
\hline 2D-Base(1) & $6,058.15$ & $40,356.18$ & 364.81 \\
\hline A SW(2) & $6,325.46$ & $40,784.72$ & 378.41 \\
\hline$(2)-(1)$ & 267.31 & 428.54 & 13.59 \\
\hline Diff. ((2)-(1)/(1)) & $\mathbf{4 . 4 \%}$ & $\mathbf{1 . 1 \%}$ & $\mathbf{3 . 7 \%}$ \\
\hline B SW(3) & $6,048.26$ & $39,037.15$ & 285.39 \\
\hline$(3)-(1)$ & -9.90 & $-1,319.03$ & -79.43 \\
\hline Diff. ((3)-(1)/(1)) & $\mathbf{- 0 . 2 \%}$ & $\mathbf{- 3 . 3 \%}$ & $\mathbf{- 2 1 . 8 \%}$ \\
\hline C SW(4) & $5,997.43$ & $37,826.98$ & 302.03 \\
\hline$(4)-(1)$ & -60.73 & $-2,529.20$ & -62.78 \\
\hline Diff. ((4)-(1)/(1)) & $\mathbf{- 1 . 0 \%}$ & $\mathbf{- 6 . 3 \%}$ & $\mathbf{- 1 7 . 2 \%}$ \\
\hline
\end{tabular}

게 차이가 나지 않는 것으로 파악되었다. 그러나 철근 물량은 벽체가 차지하는 비율이 크다 보니 벽체의 각종 보강, 벽체 끝 단의 정착 또는 U-bar의 반영이 이루어지지 않아 크게 차이를 나타내는 것으로 파악되었다.

$\mathrm{C}$ 제품의 경우는 앞의 생활관 사례와 마찬가지로 물량산출 을 위한 템플릿을 적용하여 공제 또는 추가 설정을 하도록 되 어 있어, $\mathrm{B}$ 제품의 산출 물량과는 차이를 보이는 것으로 파악되 었다.

콘크리트, 거푸집, 철근의 층별 산출물량은 Table $8,9,10$ 과 같다.

동일한 모델 조건에서 산출된 물량을 비교하여 보기 위하여 기준층을 비교해 보았을 때 전체 물량의 비교와 비슷하게 나타 났으며, 형태가 달라지는 지하층, 1,2 층, 옥상층, 옥탑층 등은 각각 차이가 다양하게 나타났다. 이는 각 프로그램별로 부재 를 어떤 층에 종속시키는지의 차이에 의한 것으로 $\mathrm{A}$ 제품과 $\mathrm{C}$ 제품은 지상층 바닥의 구조는 지하층에 종속되는데 반해 $\mathrm{B}$ 제 품에서는 1 층에 종속되는 것으로 파악되었다.

\section{5. 결 론}

이상과 같이 철근콘크리트 구조 중 RC구조와 벽식 구조 두 종류 구조형식을 사용한 프로젝트에서 BIM모델을 작성하여 콘크리트, 거푸집, 철근의 물량을 산출하고, $2 \mathrm{D}$ 기반으로 산출 한 물량과 비교하여 각각의 특성과 차이를 알아보았다.

사례연구를 위하여 적용해 본 세 가지 프로그램 이외에도 많은 프로그램들이 BIM 기반의 물량을 산출할 수 있도록 출시 되고 있다. 그러나 본 연구 사례와 같이 각각 차이가 나타나는 부분과 보완해야 할 부분들을 도출할 수 있었다.

1) 매스 형태 기반의 물량산출 프로그램(A 제품)의 경우, 보 다 정확한 물량산출을 위하여 꾸준한 산출 데이터의 확보 를 통하여 산출식을 지속적으로 보완할 필요가 있다.

2) $\mathrm{BIM}$ 모델 기반 산출 프로그램(B제품, $\mathrm{C}$ 제품)의 경우, 큰 크리트와 거푸집의 물량은 모델의 형상정보를 불러 산 출하기 때문에 비교적 정확한 물량을 산출할 수 있다.

3) 철근의 물량산출은 $\mathrm{BIM}$ 기반으로 산출한 물량이 $2 \mathrm{D}$ 기반 으로 산출한 물량보다 상당히 적게 나타나는데, 이를 파악 하기 위해서는 철근 시공 물량과 비교·검토가 필요하다.

\section{6. 연구의 한계 및 시사점}

물량산출은 정답이 없다고 할 수 있다. 비교 검토의 대상으 로 삼은 $2 \mathrm{D}$ 기반 산출물량이 $100 \%$ 정답이라고 할 수 없으며, 
Table 8 Comparison of 2D-base and BIM base quantity take-off(concrete)

\begin{tabular}{|c|c|c|c|c|c|c|c|}
\hline Floor & 2D & A SW & Diff. to 2D(\%) & B SW & Diff. to 2D(\%) & C SW & Diff. to 2D(\%) \\
\hline Foundation + B1 & $1,188.66$ & $1,305.27$ & $9.8 \%$ & 955.63 & $-19.2 \%$ & $1,156.85$ & $-2.7 \%$ \\
\hline $1 \mathrm{~F}$ & 175.28 & 180.30 & $2.9 \%$ & 318.99 & $82.0 \%$ & 177.84 & $1.5 \%$ \\
\hline $2 \mathrm{~F}$ & 181.86 & 187.03 & $2.8 \%$ & 178.02 & $-2.1 \%$ & 177.10 & $-2.6 \%$ \\
\hline Typ. Floor(3 26F) & 176.91 & 182.52 & $3.2 \%$ & 178.37 & $0.8 \%$ & 177.10 & $0.1 \%$ \\
\hline 27F & 174.31 & 179.99 & $3.3 \%$ & 183.60 & $5.3 \%$ & 171.05 & $-1.9 \%$ \\
\hline Roof Floor & 92.33 & 92.34 & $0.0 \%$ & 138.54 & $50.1 \%$ & 64.01 & $-30.7 \%$ \\
\hline Sum & $6,058.15$ & $5,020.19$ & $-17.1 \%$ & $5,092.62$ & $-15.9 \%$ & $4,840.58$ & $-20.1 \%$ \\
\hline
\end{tabular}

Table 9 Comparison of 2D-base and BIM base quantity take-off(form)

\begin{tabular}{|c|c|c|c|c|c|c|c|}
\hline Floor & 2D & A SW & Diff. to 2D(\%) & B SW & Diff. to 2D(\%) & C SW & Diff. to 2D(\%) \\
\hline Foundation + B1 & $2,558.36$ & $2,615.58$ & $2.2 \%$ & $1,860.09$ & $-27.3 \%$ & $2,505.29$ & $-2.1 \%$ \\
\hline $1 \mathrm{~F}$ & $1,387.12$ & $1,397.78$ & $0.8 \%$ & $1,823.25$ & $31.4 \%$ & $1,297.71$ & $-6.4 \%$ \\
\hline $2 \mathrm{~F}$ & $1,398.68$ & $1,408.86$ & $0.7 \%$ & $1,338.09$ & $-4.3 \%$ & $1,281.23$ & $-8.4 \%$ \\
\hline Typ. Floor(3 26F) & $1,361.25$ & $1,375.35$ & $1.0 \%$ & $1,341.30$ & $-1.5 \%$ & $1,280.19$ & $-6.0 \%$ \\
\hline 27F & $1,443.15$ & $1,453.91$ & $0.7 \%$ & $1,395.11$ & $-3.3 \%$ & $1,474.48$ & $2.2 \%$ \\
\hline Roof Floor & 898.87 & 899.05 & $0.0 \%$ & $1,036.32$ & $15.3 \%$ & 544.06 & $-39.5 \%$ \\
\hline Sum & $37,797.82$ & $38,169.14$ & $1.0 \%$ & $37,177.07$ & $-1.6 \%$ & $35,321.69$ & $-6.6 \%$ \\
\hline
\end{tabular}

Table 10 Comparison of 2D-base and BIM base quantity take-off(rebar)

\begin{tabular}{|c|c|c|r|r|r|r|r|}
\hline Floor & 2D & A SW & Diff. to 2D(\%) & B SW & Diff. to 2D(\%) & C SW & Diff. to 2D(\%) \\
\hline Foundation + B1 & 86.19 & 88.48 & $2.7 \%$ & 41.63 & $-51.7 \%$ & 70.43 & $-18.3 \%$ \\
\hline 1F & 13.98 & 14.49 & $3.7 \%$ & 21.11 & $51.0 \%$ & 14.98 & $7.2 \%$ \\
\hline 2F & 11.79 & 12.25 & $3.9 \%$ & 9.81 & $-16.8 \%$ & 10.02 & $-15.0 \%$ \\
\hline Typ. Floor(3 26F) & 10.90 & 11.34 & $4.0 \%$ & 9.58 & $-12.1 \%$ & 9.43 & $-13.5 \%$ \\
\hline 27F & 9.27 & 9.64 & $4.0 \%$ & 8.26 & $-10.9 \%$ & 7.62 & $-17.8 \%$ \\
\hline Roof Floor & 12.53 & 12.96 & $3.4 \%$ & 6.03 & $-51.9 \%$ & 3.23 & $-74.2 \%$ \\
\hline Sum & 278.63 & 289.93 & $4.1 \%$ & 243.75 & $-12.5 \%$ & 231.60 & $-16.9 \%$ \\
\hline
\end{tabular}

이는 $2 \mathrm{D}$ 기반 산출물량이 산출 작업자마다 경험과 각자의 노 하우에 의한 부분이 상당 존재하기 때문이다.

$\mathrm{BIM}$ 기반의 물량산출은 이러한 개인의 역량에 의한 차이를 최소한으로 하고, 정확한 형상정보와 산출식에 의존하여 누구 든 같은 결과를 만들 수 있도록 하는데 있다.

본 사례연구는 설계자가 최종 물량산출과 견적을 작성하기 전 물량을 산출할 수 있는 BIM모델기반의 소프트웨어를 활용 하여 물량을 산출하여 작업 중인 프로젝트가 적절한 예정공사 비의 범주에 들어가고 있는지를 확인하여 추후 재설계나 설계 변경에 들어가는 부담을 완화하고, 견적작업자가 산출한 물량 이 적절한지 검토하는데 유용한지, 어떤 부분들에서 차이가 발생하는지 알아보고자 하였으며, 향후 BIM기반 물량산출의 정확도를 검증을 위하여 실제 공사 투입 물량 자료를 확보하여 추가 비교 · 연구를 할 필요가 있겠다.

\section{References}

An, J.W., Yun, S.H. (2017) Improvement of BoQ Documents for the BIM based Quantity Takeoff, J. KIBIM, 7(2), pp.16 24.

Choi, H.C. Lee, Y.J., Lee, S.E., Kim, C.K. (2014) Development of 3-Dimensional Rebar Detail Design and Placing Drawing System, J. Comput. Struct. Eng, Inst, Korea, 27(4), pp.289 296.

Chung, S.W., Kwon, S.W. (2014) Framework of Conceptual Estimation Model for BIM based Internal Finishes of High-rise Building Project, J. Constr. Eng. \& Manag., 15(2), pp.53 61.

Joo, S.U., Kim, C.K. Kim, S.U., Noh, J.O. (2017) BIM-Based Quantity Takeoff and Cost Estimation Guidelines for Rainforced Concrete Structures, J. Comut. Struct. Eng, Inst, Korea, 30(6), pp.567 576. 
Jun, K.H., Yun, S.H. (2011) The Case Study of BIM-based Quantity Take-off for Concrete and Formwork, J. KIBIM, 1(1), pp.13 17.

Kim, J.H., Yoon, S.W. (2013) A Verification of the Accuracy in BIM-based Quantity Taking-Off Focusing on Finishing Work, J. KIBIM, 3(2), pp.1 9.

Kim, T.H., Hong, C.G., Kim, S.K. (2003) Algorithm for the Reinforced Concrete Framework Materials Take-off, J. Constr. Eng. \& Proj. Manag., 4(1), pp.114 121.

Kim, Y.J., Kim, S.A., Chin, S.Y. (2012) A Study of BIM based Estimation Modeling Data Reliability Improvement, J. Constr. Eng. \& Manag., 3(3), pp.43 55.

Kwon, O.C., Jo, C.W., Cho, J.W. (2011) Introduction of BIM Quality Standard for Quantity Take-off, J. Korea Inst. Build. Constr., 11(2), pp.171 180.

Min, K.H., Kim, S.J. (2016) Comparison Analysis of Concrete Material Take-off of Structural Frame Work Based on BIM, J. Constr. Eng. \& Manag., 2016-11, pp.112 115.

Park, Y.J., Won, S.K., Han, C.H., Lee, J.B. (2011) A Study on 3D
BIM Collaborative Approximate Estimating Model of Structural Work for Apartment Projects, J. Archi. Inst. Korea, 27(6), pp.123 130.

Shin, J.C., Ahn, S.R. (2013) Analysis of Errors and Reliability in Earth-Volume and Retaining wall Quantity Estimations with 3D-BIM Compared with Routine Method Based 2D, J. KIBIM, 3(1), pp.25 26.

Song, C.H., Kim, C.K., Lee, S.E., Choi, H.C. (2016) Establishment of Rebar Quantity Estimation in BIM-based Initial Design Phase, J. Comput. Struct. Eng, Inst, Korea, 29(5), pp.447 454.

Yoo, J.E., Lee, C.S. (2015) Comparison of Quantity Take-off based on BIM and 2D, J. Constr. Eng. \& Manag., 2015-11, pp.127 130.

Yoon, M.C. (2013) A BIM-Based Architectural Model Takes Advantage of the Estimate Model Process, J. Archi. Inst. Korea, 29(9), pp.95 102.

\section{요 지}

최근 건설업계에서 설계시의 수량산출 및 예정공사비의 정확도에 대한 요구가 높아지고 있으며, 설계변경 시에 즉각적인 물량의 변화와 공사비의 변화를 파악하는 것이 중요한 이슈가 되고 있다. 또한, 수량과 공사비와 관련한 각종 소송들이 빈번하게 발생하면서 이를 해결하기 위한 방안으로 BIM기반의 물량산출 및 견적이 대안으로 등장하였다. 그러나 현재 BIM기반의 물량산출 및 견적은 2D 기반의 기존 방식보다 활용이 원활하지 못하다. 이는 물량산출 및 내역에 대한 국가적인 표준이나 기준이 마련되어 있지 못하고, 산출 작업자의 경험이 중요한 요소로 작용하기 때문이다. 하지만, 이는 견적의 관점이고 설계자의 관점에서 $\mathrm{BIM}$ 을 이용한 즉각적이고 비 교적 정확도가 우수한 수량과 공사비의 파악이 예산에 맞는 설계를 진행하기 위하여 필요하다. 본 연구에서는 서울시 OO타운 생활관 의 철근콘크리트 구조의 콘크리트, 철근, 거푸집의 수량을 사례로 $2 \mathrm{D}$ 기반의 설계수량과 $\mathrm{BIM}$ 을 기반으로 한 계획설계, 실시설계 시의 수량과 실제 시공수량을 비교·분석하고 차이가 발생하는 원인을 분석하여 향후 설계자 관점에서 BIM기반의 수량산출에 도움이 되고 자 하였다.

핵심용어 : 수량산출, 철근, 콘크리트 물량, 개산견적, 빌딩정보보델 